\title{
WEED INTERFERENCE IN EGGPLANT CROPS ${ }^{1}$
}

\author{
LUIZ JUNIOR PEREIRA MARQUES ${ }^{*}$, SILVANO BIANCO ${ }^{3}$, ARTHUR BERNARDES CECÍLIO FILHO $^{4}$, \\ MATHEUS SARAIVA BIANCO ${ }^{5}$, GISLANE DA SILVA LOPES ${ }^{6}$
}

\begin{abstract}
Uncontrolled weed growth interferes with the growth eggplants and crop yields. To control weeds, the main weed species must be identified in crop growing areas and during weed control periods, as weed species might vary in relation to management practices. Therefore, this study aimed to identify the main weed species and determine the periods of weed interference in the eggplant cultivar Nápoli when grown under certain cultural practices, including plant staking and sprout thinning. The experiment was carried out in 2014 using a randomized complete block design, with 3 replications. The treatments consisted of 11 periods of (1) increasing weed control and (2) increasing coexistence of eggplant with weeds from the first day of transplanting $(0-14,0-28,0-42,0-56,0-70,0-84,0-98,0-112,0-126,0-140$, and up do day 154). Eggplant staking and sprout thinning were performed 42 days after transplanting (DAT). Weed identification and crop yield assessments were performed to determine the Period Before Interference (PBI), Total Period of Interference Prevention (TPIP), and the Critical Period of Interference Prevention (CPIP). The major weeds found in the eggplant cultivar Nápoli were Eleusine indica, Portulaca oleracea, and Cyperus rotundus. Coexistence between the weed community and the eggplant throughout the entire crop production cycle reduced eggplant fruit yield by 78\%. The PBI was 29 DAT and the TPIP was 48 DAT, resulting in 19 days of CPIP.
\end{abstract}

Keywords: Competition. Weed community. Solanum melongena L.. Management practices.

\section{INTERFERÊNCIA DAS PLANTAS DANINHAS NA CULTURA DA BERINJELA}

RESUMO - As plantas daninhas, quando manejadas incorretamente, podem interferir no desenvolvimento e produtividade da berinjela. Para o controle destas plantas é fundamental identificar as principais espécies infestantes do local de cultivo e os períodos de controle, que podem variar de acordo com as práticas de manejo adotadas. Desta forma, o objetivo deste estudo foi identificar as principais plantas daninhas e determinar os períodos de interferência na cultura da berinjela cultiva 'Nápoli' sob manejo de tutoramento e desbrota. O experimento foi realizado no ano de 2014 no delineamento de blocos ao acaso, com três repetições. Os tratamentos consistiram de 11 períodos crescentes de controle e convivência com as plantas daninhas a partir do transplante: $(0-14,0-28,0-42,0-56,0-70,0-84,0-98,0-112,0-126,0-140$ e 0-154 dias). As práticas de tutoramento e desbrota ocorreram aos 42 dias após o transplante (DAT). Realizou-se a identificação das plantas daninhas e avaliação da produtividade da cultura para determinação do período anterior à interferência (PAI), do período total de interferência (PTPI) e do período crítico de prevenção a interferência (PCPI). As principais plantas daninhas encontradas na cultura da berinjela 'Nápoli' foram Eleusine indica, Portulaca oleracea e Cyperus rotundus. O convívio entre comunidade infestante e cultura durante todo o ciclo da berinjela reduziu a produtividade de frutos em 78\%. O PAI foi de 29 DAT e o PTPI de 48 DAT, resultando em 19 dias de PCPI.

Palavras-chaves: Competição. Comunidade infestante. Solanum melongena L.. Práticas de manejo.

\footnotetext{
${ }^{*}$ Corresponding author

${ }^{1}$ Received for publication in $07 / 02 / 2016$; accepted in $03 / 05 / 2017$.

Paper extracted from the doctoral thesis of the first author.

${ }^{2}$ Educational development director, Instituto Federal de Educação Ciência e Tencologia do Maranhão, Barra do Corda, MA, Brazil; luiz.marques@ifma.edu.br.

${ }^{3}$ Department of applied biology to agriculture, Universidade Estadual Paulista, Jaboticabal, SP, Brazil; sbianco@fcav.unesp.br.

${ }^{4}$ Department of vegetables production, Universidade Estadual Paulista - Campus Jaboticabal, Jaboticabal, SP, Brazil; rutra@fcav.unesp.br.

${ }^{5}$ Unit I, Centro Universitário do Rio Preto, São José do Rio Preto, SP, Brazil; matbianco2004@yahoo.com.br.

${ }^{6}$ Department of Fitotecnia, Universidade Estadual do Maranhão, São Luis, MA, Brazil; gslopes11@yahoo.com.br.
} 


\section{INTRODUCTION}

The eggplant (Solanum melongena L.) is a vegetable fruit grown globally. In the state of São Paulo, Brazil, eggplant production systems occupy 1,037 ha, produce 47,549 t eggplant, and generate 1,023 jobs. The main municipalities that produce eggplant are Campinas (6.4\%), Aguaí and São José do Rio Pardo (5.5\%), Monte Alto (5.4\%), Elias Fausto, Itapecerica da Serra (4.9\%), and Alvares Machado (4.1\%) (CEAGESP, 2015).

Although the eggplant plant is a semi-shrub and has woody stems, plant staking and sprout thinning are often recommended as management practices to prevent the plants from tipping or breaking (EMBRAPA HORTALIÇAS., 2014). These management practices are beneficial to the crops and affect weed control, as they alter environmental factors within the crop. For example, in tomato production systems, plant staking improves how solar radiation is distributed across the plant canopy (WAMSER et al., 2007). Furthermore, sprout thinning prevents leaves and fruits touching the soil and improves aeration, enhancing solar radiation to the plant and the implementation of cultural practices (MIRANDA et al., 2011).

Uncontrolled weed growth reduces crop yields. For example, weeds reduce okra and carrot crop yields by up to $95 \%$ (BACHEGA et al., 2013) and 94\% (COELHO; BIANCO; CARVALHO, 2009), respectively. In eggplant cultivation, weeds reduce fruit yield and quality by $67 \%$ and 96\%, respectively (ARAMENDIZ-TATIS; CARDONA-AYALA; DE ORO, 2010).

To manage weeds effectively, it is essential to identify the major weed species in crop growing areas and to determine the key periods of weed interference. The importance of the weed community is determined by calculating various phytosociological parameters, such as relative density, relative frequency, relative dominance, and relative importance. Interference periods indicate the time at which control is not necessary, because of the absence of negative interactions between weeds and crops, and the appropriate time to perform weed control in crops.

Studies on weed interference carried out in different vegetable crops have suggested when weed control should be implemented. For instance, in okra in the State of São Paulo and State of Minas Gerais, it should be implemented up to 57 days and 75-100 days after crop emergence (DAE), respectively (BACHEGA et al., 2013; SANTOS et al., 2010). The weed control of beet depends on the management practice; for instance, it should be carried out between 51 and 35 days after transplanting beet, but between 14 and 36 days when sowing beet directly in the soil (CARVALHO et al., 2008a, b). In contrast, the eggplant cultivar Lila, which is widely grown in Colombia, should not coexist with weeds in the first 40 DAE (ARAMENDIZ-TATIS; CARDONA-AYALA; DE ORO, 2010).

Variation in weed interference periods for agricultural crops is directly related to the management practice being implemented, geographic region, crop type, cultivar, and species of weeds present in the crop production system. To inform the decision making process for the control of weeds in eggplant cultivation, this study aimed to identify the major weeds and key periods of interference with the eggplant cultivar Nápoli grown under different cultural practices, such as plant staking and sprout thinning.

\section{MATERIAL AND METHODS}

The experiment was conducted in 2014 in the Municipality of Jaboticabal, State of São Paulo (SP), Brazil, (latitude $21^{\circ} 5^{\prime} 22^{\prime \prime} \mathrm{S}$, longitude $48^{\circ} 18^{\prime} 58^{\prime \prime} \mathrm{W}$, and at an altitude of $\left.575 \mathrm{~m}\right)$. The climate of the region is Cwa type, according to Köppen classification, with predominant summer rains and relatively dry winters (ANDRÉ; VOLPE, 1982). The mean values of the maximum and minimum temperatures and monthly rainfall during the experimental period are presented in Table 1.

The soil at the experimental site was classified as typical Eutrodox Red, moderate A, caulinitic-oxidic, of clay texture (ANDRIOLI; CENTURION, 1999). The land was prepared using a heavy harrow, followed by a leveling harrow, and, finally, a furrower regulated to $1.5 \mathrm{~m}$ between rows. Basal mineral fertilization ( $150 \mathrm{~g} \mathrm{~m}^{-1}$ of formulation 4-14-8 nitrogen [N], phosphorus [P], and potassium $[\mathrm{K}])$ was added to the furrows at transplanting. Topdressing $\left(7 \mathrm{~g} \mathrm{~m}^{-1}\right.$ ammonium sulfate $+3.5 \mathrm{~g} \mathrm{~m}^{-1}$ potassium chloride) was added every 15 days after transplanting. Liming of the whole experimental area was performed 15 days before transplanting, by applying $150 \mathrm{~g} \mathrm{~m}^{-2}$ calcined lime with effective calcium carbonate equivalent (ECCE) of lime material $=95 \%, \mathrm{CaO}=34 \%$, and $\mathrm{MgO}=17 \%$. Basal and topdressing fertilization, as well as soil acidity correction, was performed following the recommendations of Trani et al. (1996) based on soil analyses results (Table 2). 
Table 1. Climatic conditions during the experimental period, 2014.

\begin{tabular}{lccccc}
\hline Month & Max T $\left({ }^{\circ} \mathbf{C}\right)$ & Min T $\left({ }^{\circ} \mathbf{C}\right)$ & $\operatorname{Av~T~}\left({ }^{\circ} \mathbf{C}\right)$ & Rainfall (mm) & Insolation (H) \\
\hline February & 32.5 & 19.9 & 25.5 & 83.0 & 233.9 \\
March & 30.9 & 19.5 & 24.1 & 106.8 & 238.4 \\
April & 30.1 & 17.9 & 23.0 & 63.3 & 241.2 \\
May & 28.0 & 14.6 & 20.2 & 6.7 & 237.4 \\
June & 28.6 & 13.7 & 20.0 & 1.8 & 238.7 \\
July & 27.1 & 13.1 & 19.1 & 30.0 & 212.2 \\
\hline
\end{tabular}

Source: Agroclimatological Station - FCAV/UNESP/Jaboticabal.

Table 2. Chemical characteristics of the soil at the experimental site. The methods used for the chemical analyses and for determining granulometry are described in Raij et al., (2001).

\begin{tabular}{|c|c|c|c|c|c|c|c|c|c|}
\hline $\mathrm{pH}$ & $\mathrm{OM}$ & $\mathrm{P}_{\text {resin }}$ & $\mathrm{K}$ & $\mathrm{Ca}$ & $\mathrm{Mg}$ & $\mathrm{H}+\mathrm{Al}$ & $\mathrm{CEC}$ & $\mathrm{SB}$ & $\mathrm{V}$ \\
\hline $\mathrm{CaCl}_{2}$ & $\mathrm{~g} \mathrm{dm}^{-3}$ & $\mathrm{Mg} \mathrm{dm}^{-3}$ & ----- & --- & $\mathrm{c}_{\mathrm{dm}}^{-3}$ & - & & & $\%$ \\
\hline 5.3 & 17 & 79 & 4.6 & 26 & 12 & 28 & 70.6 & 42.6 & 60 \\
\hline
\end{tabular}

The eggplant cultivar used in the experiment was Nápoli, the fruit of which (color, shape, weight, and size) are accepted by the market. This plant grows vigorously, with high fruit yield potential (EMBRAPA HORTALIÇAS., 2014). The seedlings of this plant are widely available in the State of São Paulo. The seedlings of this cultivar were supplied in trays from a specialized producer, and were transplanted to the field once four leaves were present. Transplanted seedlings were planted with a spacing of $1.5 \mathrm{~m}$ between rows and $1.0 \mathrm{~m}$ between plants on February 1, 2014. Eggplant staking was performed at $42 \mathrm{DAT}$, and sprout thinning was carried out regularly throughout plant growth. These management practices are important to prevent the stem from breaking or the plants from tipping due to the excessive weight of the fruit, and enhance crop longevity.

Cultural practices recommended to control the pests and diseases of the eggplant cultivar Nápoli were carried out throughout the experiment (with biweekly applications). The agrochemicals used included EVIDENCE $700 \mathrm{WG}$ to control white flies, green aphids, and thrips; DECIS 25 EC to control small fruit borers, leaf miners, lace bugs, yellow green leaf beetles, solanaceous leaf beetles, and cutworms; CERCOBIN to control anthracnose, gray mold, and Sclerotinia rot; and AMISTAR TOP® to control Ascochyta rot. Moreover, sprinkler irrigation was implemented to provide $5 \mathrm{~mm}$ of water daily.

The experiment was laid out in a randomized complete block design. The treatments consisted of 11 periods of (1) increasing coexistence of eggplant with weeds and (2) increasing weed control from the first day of transplanting the eggplant cultivar Napoli to day 154 . The crop was separated into 2 groups, with 22 treatments in total and 3 replications. In the first group, eggplants coexisted with weeds following transplanting until the growing periods of $0-14,0-28,0-42,0-56,0-70,0-84,0-98,0-112$, $0-126,0-140$, and $0-154$ days. After each of these periods, the weeds were controlled manually until harvest. In the second group, the eggplants were maintained weed-free by hand weeding, following transplanting, until the end of the same periods.

Each plot contained 3 rows ( 5 plants per row), covering a total of $22.5 \mathrm{~m}^{2}$. Only the central row of each plot was used for the experiment, covering $4.5 \mathrm{~m}^{2}$. The border was composed of the lateral rows, as well as the plants were located at the beginning and the end of the central row.

The weed community in the treatments was evaluated during the initial periods of weed coexistence with the eggplant and at the end of each period (i.e., 0-14, 0-28, 0-42, 0-56, 0-70, 0-84, $0-98,0-112,0-126,0-140$, and $0-154$ days). In the treatments with initial periods of weed control, weeds were only evaluated at the end of the last period, i.e., at $154 \mathrm{DAT}$.

The infesting weed community present in the coexistence treatments was evaluated using a metal frame of $0.25 \mathrm{~m}^{2}$, which was placed 3 times in each plot. All weeds present in the area covered by the sampling frame were collected, identified, separated by species, counted, placed in paper bags, and dried in a $65{ }^{\circ} \mathrm{C}$ air exchange oven for $72 \mathrm{~h}$. The dry mass of weeds was determined using a $0.01 \mathrm{~g}$ precision scale. The data were used to compute the following 
phytosociological parameters: relative density (R. De), which reflects the relevance of the weed population in numerical terms; relative frequency $(R$. Fr), which reflects the relevance of the weed population in terms of area of occupation; relative dominance (R. Do), which reflects the accumulation of dry mass; and importance value index (IVI) and Relative importance (RI) values of each species, which reflect the relevance of the weed community population (MUELLER-DOMBOIS; ELLENBERG, 1974).

$$
\text { R. } D e=(N i / N t) x 100, \text { where: }
$$

R. De $=$ Relative density; $\mathrm{Ni}=$ Number of individuals of one weed population; $\mathrm{Nt}=$ Total number of individuals of the weed community.

$F r=(N S i / N S t) x 100$, where:

$\mathrm{Fr}=$ Frequency; $\mathrm{NSi}=$ number of samples in which species $\mathrm{i}$ was present; $\mathrm{NSt}=$ total number of samples collected.

$$
\text { R. Fr }=\left(\text { Fri } / \sum F r i\right) x \text { 100, where: }
$$

R. Fr= Relative frequency; Fri $=$ Frequency of a determined population.

$$
\text { R.Do }=\left(B S i / \sum B S i\right) \times 100, \text { where: }
$$

R. Do: Relative dominance; $\mathrm{BSi}=$ Biomass of a determined population.

$$
I V I=R . D e+R \text { Fr. }+ \text { R.Do. , where: }
$$

IVI: Importance value index; R. De: Relative density; R. Fr: Relative frequency; R. Do: Relative dominance.

$$
R I=\left(I V I i / \sum I V I i\right) \times 100, \text { where: }
$$
value index.

RI: Relative importance; IVI: Importance

Fruit yield was assessed across 13 weekly harvests, starting at 70 DAT. The first harvest was completed on March 31, 2014 and the last harvest was completed on July 21, 2014. All harvested fruits conformed with the market standards, i.e., each fruit was 13 to $17 \mathrm{~cm}$ in length, uniform in shape, with bright dark purple color, soft and firm flesh, green calyx, and had an average weight ranging from 180 to $250 \mathrm{~g}$ (EMBRAPA HORTALIÇAS., 2014). The fruits from each treatment were weighed at each harvest, and fruit yield was estimated in $\mathrm{kg} \mathrm{ha}^{-1}$.

Total fresh fruit mass yield data were subjected to sigmoidal regression analysis, according to the Boltzmann model:

$$
Y=A_{2}+\left[\left(A_{1}-A_{2}\right) /\left(1+e^{\left(\left(X-X_{O}\right) / D X\right)}\right)\right], \text { where, }
$$

where $\mathrm{Y}$ is the estimated eggplant fruit yield expressed in $\mathrm{kg} \mathrm{ha}^{-1}$ according to the periods of coexistence; $\mathrm{X}$ is the upper limit of the period of coexistence or of weed control (days); A1 is the maximum yield obtained in the weed free plots throughout the entire crop cycle; A2 is the minimum yield resulting from the plots that coexisted with the weeds throughout the entire crop cycle; $\mathrm{X}_{0}$ indicates the upper limit of the period of coexistence that corresponds to the intermediate value between the maximum and minimum yield; and DX is the parameter indicating the rate of yield loss or yield gain $\left(\operatorname{tg} \alpha\right.$ at point $\mathrm{X}_{0}$ ).

Regression analyses were conducted using the Origin ${ }^{\circledR} \quad 8$ program $\quad$ (ORIGINALLAB CORPORATION, USA). The graph represented eggplant fruit yield as a function of the agricultural cycle for the treatments: weed free and coexistence with the weeds. Based on the regression equations, and accepting an arbitrary level of total yield loss of $5 \%$, the following parameters were estimated for the eggplant crop: the period before interference (PBI), the total period of interference prevention (TPIP), and the critical period of interference prevention (CPIP). The PBI consists of the interval starting from the theoretical point of the greatest yield to the theoretical point corresponding to $95 \%$ of total eggplant yield in the regression equation from the weed free treatments. The TPIP consists of the interval starting from the theoretical point of the lowest yield to the theoretical point corresponding to $95 \%$ of total eggplant yield in the regression equation, originating from the treatments of eggplant coexistence with the weeds. The CPIP consists of the interval between the end of the PBI and the TPIP.

\section{RESULTS AND DISCUSSION}

A total of 16 weed species were identified in the eggplant cultivar Nápoli crop grown with plant staking and sprout thinning. These weed species included: Eleusine indica, Nicandra physalodes, Portulaca oleracea, Cyperus rotundus, Digitaria nuda, Alternanthera tenella, Amaranthus spp., Amaranthus spinosus, Amaranthus retroflexus, Amaranthus viridis, Solanum americanum, Parthenium hysterophorus, Cynodon dactylon, Indigofera hirsuta, Echinochloa colona, Eragrostis airoides, Achyrocline satureioides, Galinsoga quadriradiata, Coronopus didymus, and Digitaria insularis.

In the experiment with increasing periods of weed and eggplant coexistence, weed density was higher during the initial periods of coexistence (14 to 42 DAT) and decreased until the final stage of crop development (Figure 1). The weed species with the highest density values were $P$. oleracea and $C$. rotundus. 


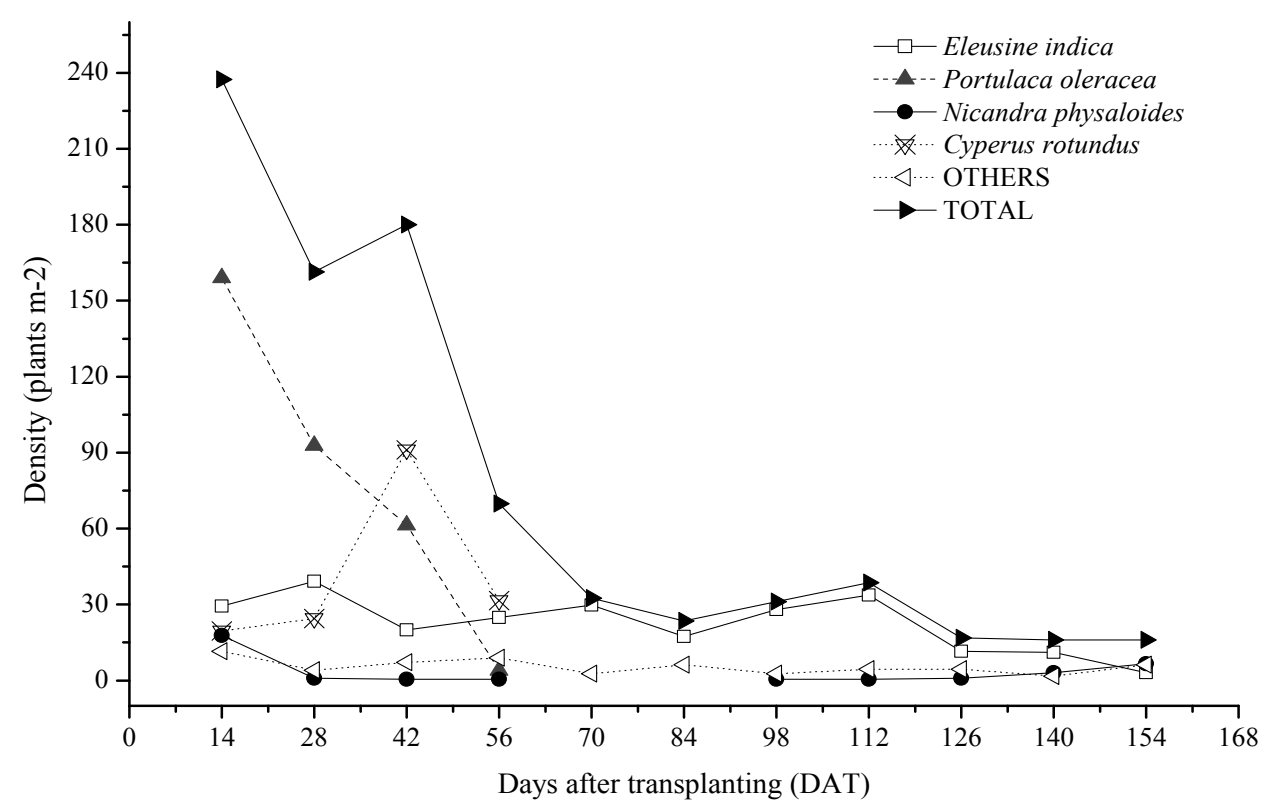

Figure 1. Major weed species and total weed community density in increasing periods of weed coexistence with the eggplant cultivar Nápoli.

The highest weed density in the treatments with increasing periods of weed control during eggplant cultivation occurred from 42 DAT (Figure 2 ), due to an increase in the density of $A$. satureioides and $C$. rotundus. The high density of $C$. rotundus might be related to the particular characteristics of the crop management, such as plant staking and sprout thinning, which favor greater light penetration and aeration in the growing area (WAMSER et al., 2007; MIRANDA et al., 2011), in addition to tuber fragmentation caused by hand-weeding, which increases $C$. rotundus regrowth.

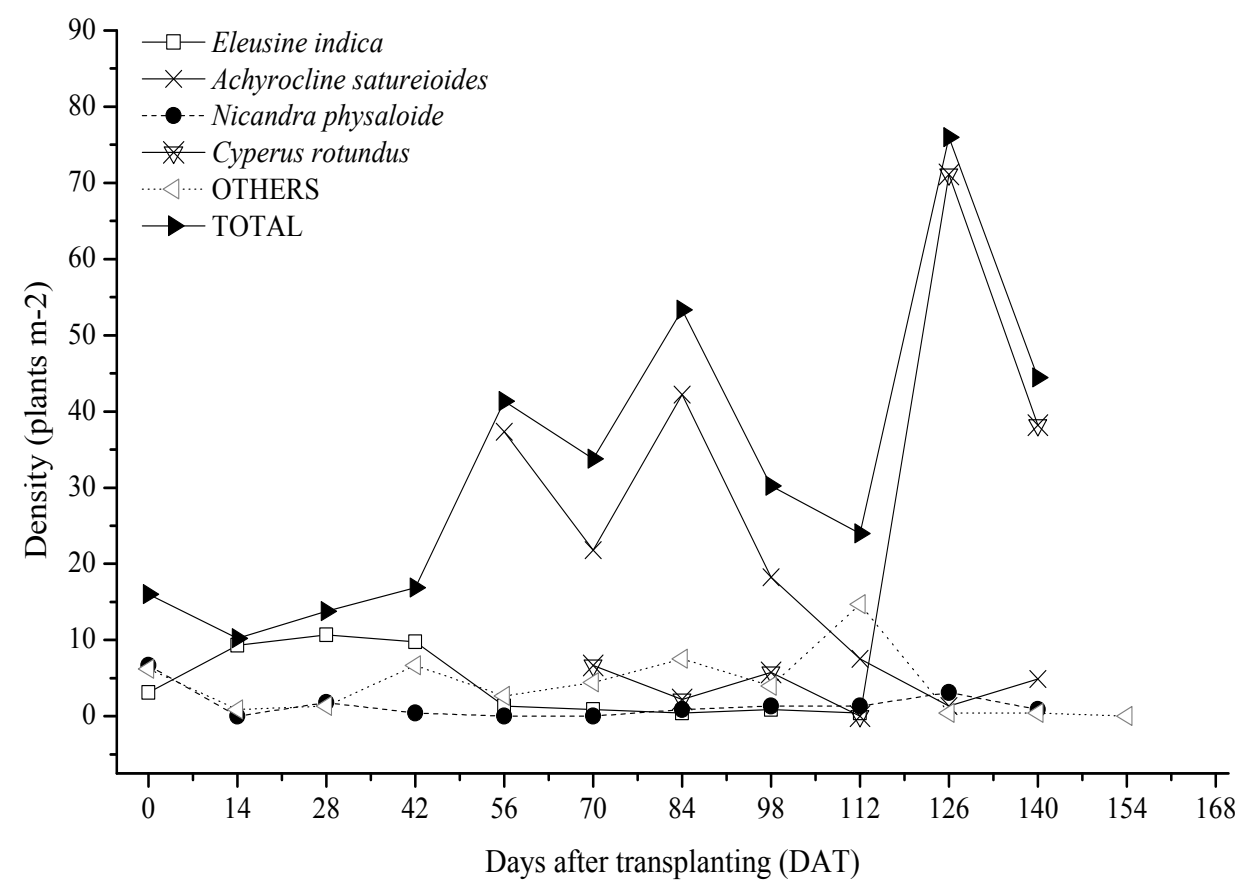

Figure 2. Major weed species and total weed community density in increasing periods of weed control in the eggplant cultivar Nápoli. 
The dry mass of weeds increased with increasing periods of interference from 42 DAT (Figure 3), with maximum accumulation occurring at 126 DAT $\left(910 \mathrm{~g} \mathrm{~m}^{-2}\right)$. These results are similar to those reported by Nascente, Pereira, and Medeiros (2004) in tomato cultivation. As the dry mass of the weeds increased, the density reduced. This phenomenon happens because, when weeds grow, particularly those that germinate at the beginning of the crop cycle, inter- and intraspecific competition intensifies, such that developed weeds become dominant and suppress the growth of less developed weeds (RAIMONDI et al., 2014).

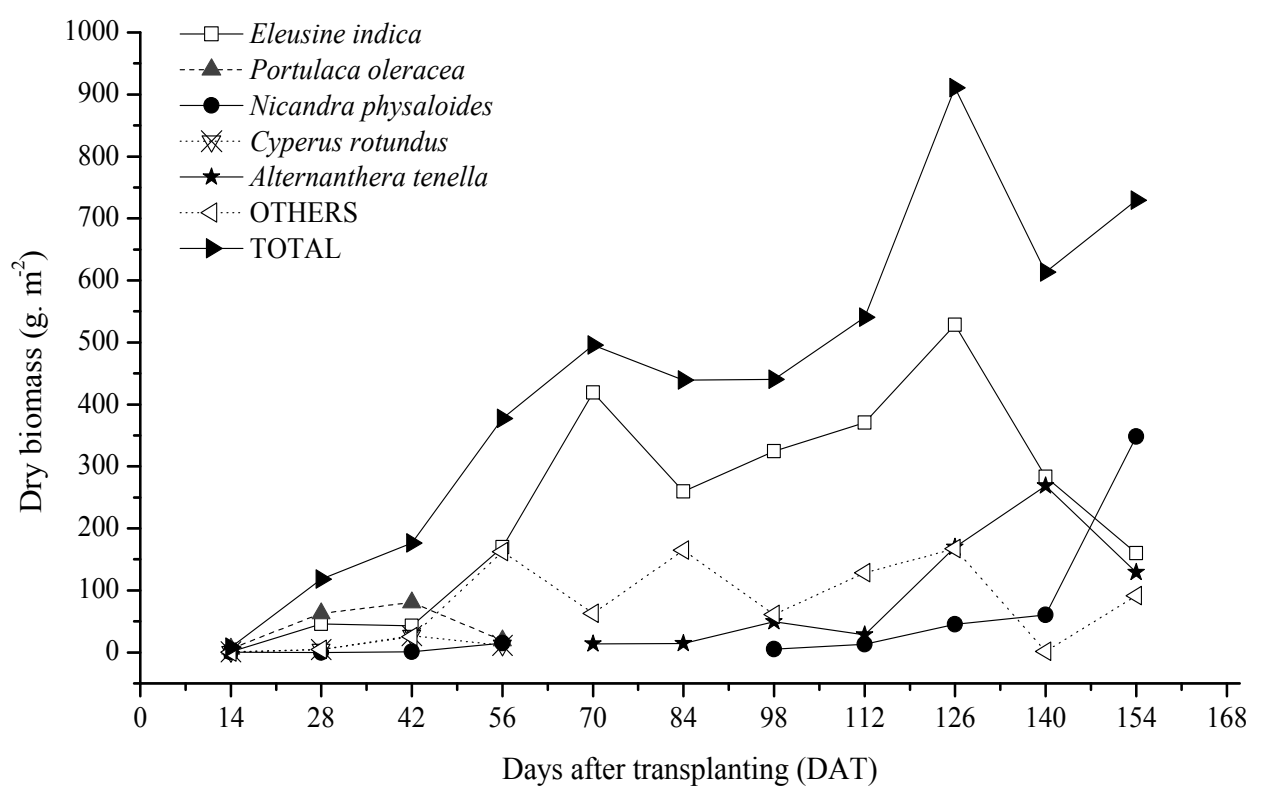

Figure 3. Dry mass of the major weed species and the dry mass of the total weed community during the growing periods of weed coexistence with the eggplant cultivar Nápoli.

The weed $E$. indica had the highest dry mass in the period from 56 to 140 DAT, while the weed $N$. physalodes had the highest dry mass at 154 DAT. The cultural practices used on crop (such as staking and sprout thinning) might have favored the growth of E. indica, which has a $\mathrm{C} 4$ cycle (CARNI; MUCINA, 1998), leading to a competitive advantage in places with high temperatures and high light conditions, which were provided by the cultural practices (CECÍLIO FILHO, 2009).

In the group of treatments of increasing periods of weed control, the dry mass of weeds decreased as weeding became constant. The highest accumulation of dry mass of the weed community occurred at 14 DAT $\left(742 \mathrm{~g} \mathrm{~m}^{-2}\right)$ with weed control, and remained high until $42 \mathrm{DAT}$, due to the greater accumulation of $E$. indica dry mass (Figure 4). After this period, weed dry mass decreased, and remained stable from 70 DAT, with a 93\% reduction in dry mass accumulation. This reduction was caused by constant weeding combined with crop growth.
Therefore, weed control practices that extend up to 84 DAT inhibit the development of the main weed species in eggplant cultivar Nápoli crops.

The weed species with the highest value of relative importance in the weed control treatments were $E$. indica, $N$. physalodes, $C$. rotundus, $P$. oleracea, and A. tenella (Figure 5). Out of these species, only $C$. rotundus has been reported in eggplant cultivation (ARAMENDIZ-TATIS; CARDONA-AYALA; DE ORO, 2010), probably due to the small number of existing experimental studies. However, the other weed species are commonly found in other vegetable crops (NASCENTE; PEREIRA; MEDEIROS, 2004; BACHEGA et al., 2013). The species C. rotundus and $P$. oleracea were prominent at the beginning of the crop cycle (from 14 to 42 DAT), while $E$. indica was prominent from $56 \mathrm{DAT}$, and both $N$. physalodes and $A$. tenella were prominent from 126 to 154 DAT. 


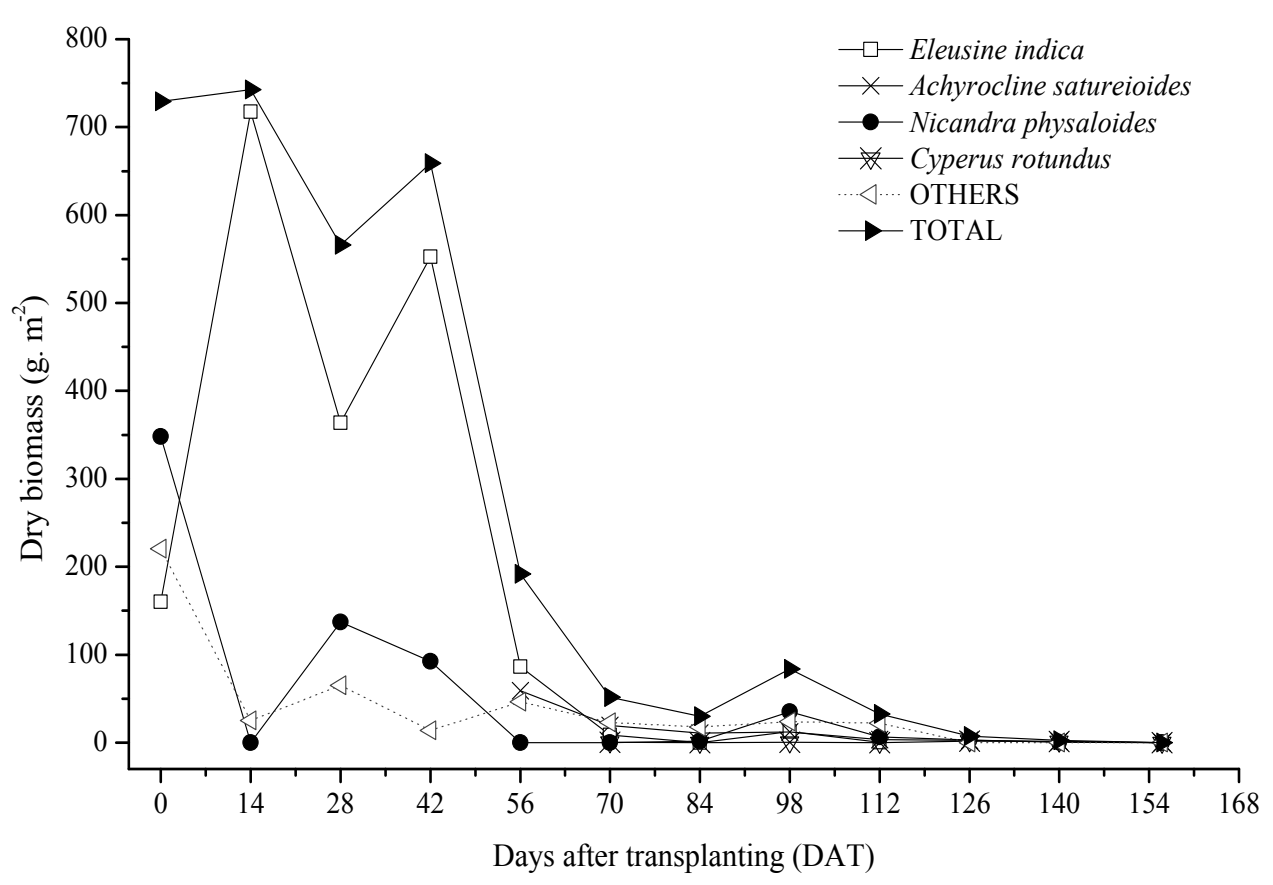

Figure 4. Dry mass of the major weeds and total weed community during the periods of weed control with the eggplant cultivar Nápoli.

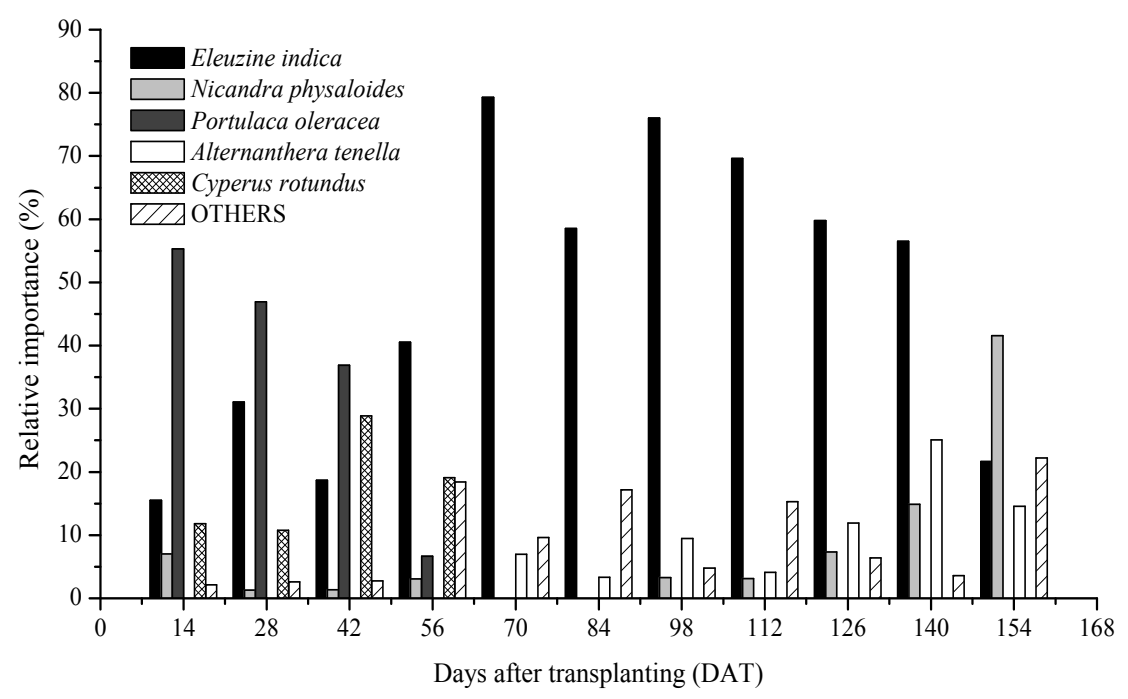

Figure 5. Relative importance values of E. indica, N. physaloides, P. oleracea, A. tenella and C. rotundus and other species from the weed community during growing periods of weed coexistence with the eggplant cultivar Nápoli.

In the treatments with increasing periods of weed control, the relative importance values of $E$. indica, N. physalodes and A. satureioides declined, whereas those of $C$. rotundus increased, as the period of weed control lengthened (Figure 6). E. indica had the highest value of relative importance in the weed community from 14 to 42 DAT. $N$. physalodes had a higher value of relative importance in the treatment with weed-eggplant coexistence, while $A$. satureioides had the highest value of relative importance when weed control was performed from 56 to 98 DAT. The value of relative importance of all other species and $C$. rotundus increased after 70 days of weed control. 


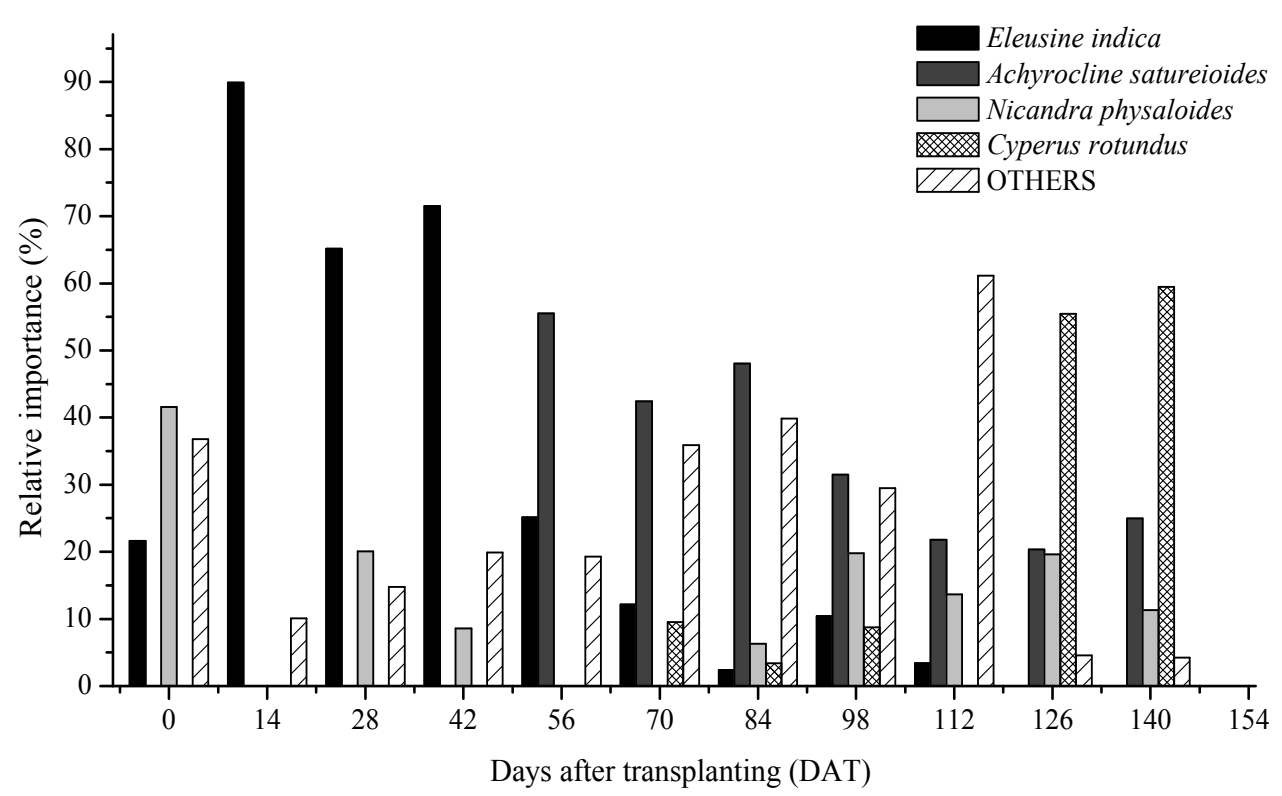

Figure 6. Relative importance values of E. indica, N. physalodes, P. oleracea, A. tenella, and C. rotundus and other species in the weed community during the growing periods with weed control for the eggplant cultivar Nápoli.

It is important to evaluate phytosociological parameters to select the appropriate weed management practices. According to Concenço et al. (2013), abundant weed species should be preferably controlled by applying herbicides before they appear, while less frequent weed species should be controlled by localized herbicide application or other management practices. Dominant weed species should be controlled with post-emergence herbicide application, preventing them from accumulating mass and dominating the field.

The period before interference (PBI) was 29 DAT, and the total period of interference prevention (TPIP) was 48 DAT; therefore, the critical period of interference prevention (CPIP) started at 29 DAT and extended until 48 DAT, lasting 19 days (Figure 7).

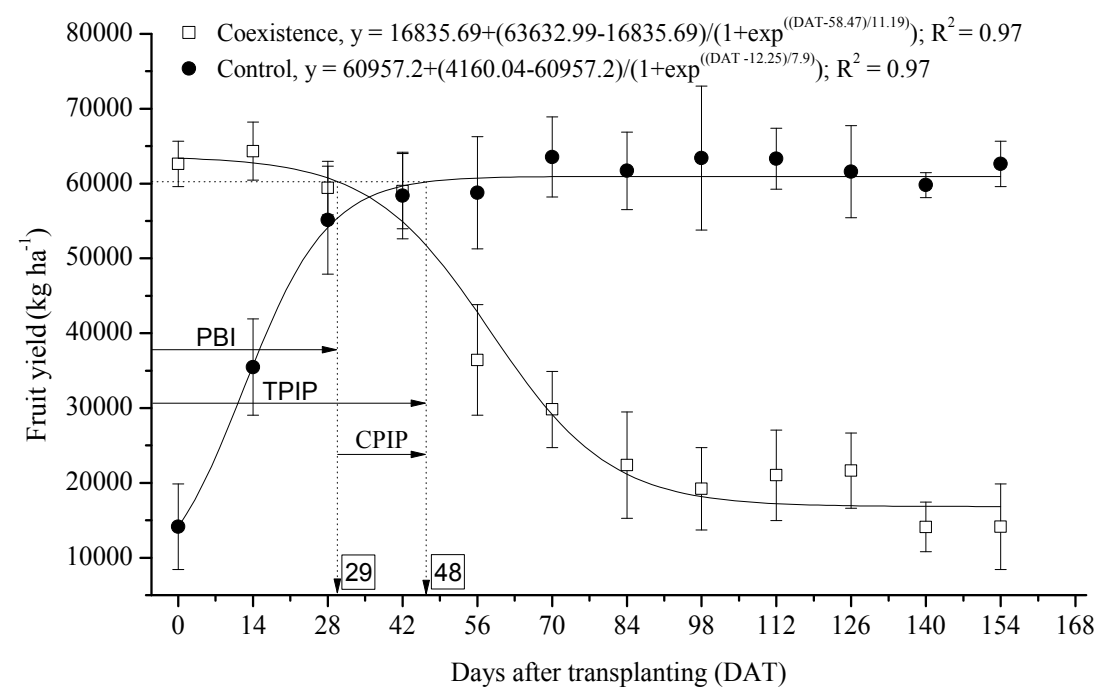

Figure 7. Total yield of eggplant cultivar Nápoli fruit in relation to increasing periods of coexistence with weeds (group of treatments of weed-eggplant coexistence) and in relation to the weed control (group of treatments with weed control).

Weed control should be effective during the CPIP, so that yield losses do not exceed $5 \%$ of the total yield, with the crop remaining weed free for most of its cycle. During PBI and after TPIP, the crop does not present greater weed interference, because nutrients are available during PBI
(PITELLI; DURIGAN, 1984) or because the crop is sufficiently developed after CPIP, allowing it to suppress the weed community (STAGNARI; PISANTE, 2011).

The results of our study support those reported by Aramendiz-tatis, Cardona-ayala and De 
Oro (2010) who investigated the cultivation of the eggplant cultivar Criollo lila. The authors found that weed control for up to 40 DAT significantly increased eggplant yield. Crop management practices, such as plant staking and sprout thinning, might have positively influenced this result, reducing the period needed for control. This phenomenon might occur because plant staking helps to limit the severity of disease or pest attack (WAMSER et al., 2008), and enhance the distribution of solar radiation across the crop canopy (WAMSER et al., 2007). Moreover, plant staking facilitates the aeration of crops, which increases fruit size and decreases attacks by pests (CECÍLIO FILHO, 2009).

The results showed that the representative weed community during PBI and after TPIP had a higher density and lower dry mass per unit area, with a maximum density of 237.33 plants $\mathrm{m}^{-2}$ (Figure 1 and 2) and a dry mass of $191 \mathrm{~g} \mathrm{~m}^{-2}$ (Figures 3 and 4). The weed species with the highest value of relative importance during these periods were $E$. indica, $C$. rotundus, $A$. satureioides, and $N$. physalodes (Figure 5 and 6).

In the CPIP, dry mass had the greatest influence on the weed community, ranging from $176.67 \mathrm{~g} \mathrm{~m}^{-2}$ to $658.8 \mathrm{~g} \mathrm{~m}^{-2}$ (Figure 3 and 4 ). $E$. indica had the highest value of relative importance during this period, particularly with respect to its relative density and relative dominance, which were represented by dry mass accumulation (Figure 5 to $6)$.

Yield reduction due to the accumulation of weed dry mass was also observed by Scholten, Parreira, and Alves (2011) in beans. These authors reported that bean yield decreased exponentially as weed dry mass increased when the bean crop coexisted with the weed community for longer periods. Similarly Horta et al. (2004) observed a high negative correlation between the accumulation of weed dry mass and commercial beet yields when the crop coexisted with weeds, or weeds were absent, during the initial growth period $\left(\mathrm{r}=-0.93^{*}\right.$ and $r=-0.94$, respectively).

Our study showed that the density and dry matter accumulation of weeds in the CPIP led to yield losses of more than $5 \%$ in treatments with weeds compared to those that remained weed free for the entire cycle. Therefore, it is important to identify the major weed species, and their respective phytosociological parameters, to select the most efficient and economical method to control weeds (CONCENÇO et al., 2013) in eggplant cultivation.

\section{CONCLUSIONS}

The weeds $E$. indica, $C$. rotundus, and $P$. oleracea were the major species responsible for interfering with eggplant cultivar Nápoli growth when using plant staking and sprout thinning practices. In conclusion, for eggplant with plant staking and sprout thinning, the CPIP starts at 29 and ends at 48 DAT, with the dry mass accumulation of the weed community causing the greatest decline in eggplant yield.

\section{ACKNOWLEDGMENTS}

We thank the Foundation for Research and Scientific and Technological Development of the State of Maranhão-FAPEMA and the Federal Institute of Education, Science and Technology of the state of Maranhão for financially supporting this article. We thank the Faculty of Agrarian and Veterinary Sciences providing space and we thank the employees José Valcir Fidelis Martins and Jamil Aparecido Ferraz from LAPDA (Laboratory of Weeds of FCAV-UNESP) for helping with fieldwork.

\section{REFERENCES}

ANDRÉ, R. G. B.; VOLPE, C. A. Dados meteorológicos de Jaboticabal no Estado de São Paulo durante os anos de 1971 a 1980. Jaboticabal, SP: FUNEP, 1982. 25 p.

ANDRIOLI, I.; CENTURION, J. F. Levantamento detalhado dos solos da Faculdade de Ciências Agrárias e Veterinárias de Jaboticabal. In: Congresso Brasileiro de Ciência do solo, 27., 1999. Brasília. Anais... Brasília: Sociedade Brasileira da Ciência do Solo, 1999. 32 p.

ARAMENDIZ-TATIS, H.; CARDONA-AYALA, C.; DE ORO, R. Período de interferência de arvenses en el cultivo de berinjela (Solanum melongena L.). Agronomía Colombiana, Bogotá, v. 28, n. 1, p. 81-88, 2010.

BACHEGA, L. P. S et al. Períodos de interferência de plantas daninhas na cultura do quiabo. Planta Daninha, Viçosa, v. 31, n. 1, p. 63-70, 2013.

CARNI, A.; MUCINA, L. Vegetation of trampled soil dominated by $\mathrm{C} 4$ plants in Europe. Journal of Vegetation Science, Malden, v. 9, n. 1, p. 45-56, 1998.

CARVALHO, L. B. et al. Interferência e estudo fitossociológico da comunidade infestante em beterraba de semeadura direta. Planta Daninha, Viçosa, v. 26, n. 2, p. 291-299, 2008 a.

CARVALHO, L. B. et al. Interferência e estudo fitossociológico da comunidade infestante na cultura da beterraba transplantada. Acta Scientiarum Agronomy, Maringá, v. 30, n. 3, p. 325-331, 2008 b.

Rev. Caatinga, Mossoró, v. 30, n. 4, p. 866 - 875, out. - dez., 2017 
CECÍLIO FILHO, A. B. Horta em casa: saúde, prazer e economia. Jaboticabal, SP: Unesp, 2009. $130 \mathrm{p}$.

COELHO, M.; BIANCO, S.; CARVALHO, L. B. Interferência de plantas daninhas na cultura da cenoura (Daucus carota). Planta Daninha, Viçosa, v. 27, Sup., p. 913-920, 2009.

\section{COMPANHIA DE ENTREPOSTOS E} ARMAZÉNS GERAIS DE SÃO PAULO CEAGESP. Berinjela: normas de classificação, 2015. Disponível em < http://www.ceagesp.gov.br/ wp-content/uploads/2015/07/berinjela.pdf $>$. Acesso em: 03 fev. 2017.

CONCENÇO, G. et al. Phytosociological surveys: tools for weed science? Planta Daninha, Viçosa, v. 31, n. 2, p. 469-482, 2013.

EMPRESA BRASILEIRA DE PESQUISA AGROPECUÁRIA - EMBRAPA HORTALIÇAS. Berinjela (Solanum melongena L.). Disponível em: $<$ http://sistemasdeproducao.cnptia.embrapa.br/

FontesHTML/Beringela/

Beringela_Solanum_melongena_L/

poscolheita.html>. Acesso em: 22 ago. 2014.

HORTA, A. C. S. et al. Interferência de plantas daninhas na beterraba transplantada e semeada diretamente. Acta Scientiarum Agronomy, Maringá, v. 26, n. 1, p. 47-53, 2004.

MIRANDA, F. R. et al. Produção de Tomate em Substrato de Fibra de Coco. 1. ed. Fortaleza: Embrapa, 2011. 20 p. (Circular técnica, 33).

MUELLER-DOMBOIS, E.; ELLENBERG, H. Aims and methods of vegetation ecology. New York: John Wiley \& Sons, 1974. 547 p.

NASCENTE, A. S.; PEREIRA, W.; MEDEIROS, M. A. Interferência das plantas daninhas na cultura do tomate para processamento. Horticultura Brasileira, Brasília, v. 22, n. 3, p. 602-606, 2004.

PITELLI, R. A; DURIGAN, J. C. Terminologia para períodos de controle e de convivência das plantas daninhas em culturas anuais e bianuais. In: Congresso brasileiro de herbicidas e plantas daninhas, e VI Congreso de la asociacion latinoamericana de malezas (ALAM) 15., 1984, Belo Horizonte. Anais... Belo Horizonte: SBHED, 1984. p. 37.

RAIJ, B. V. et al. Análise química para avaliação da fertilidade de solos tropicais. 1. ed. Campinas, SP: IAC, 2001. 285 p.

RAIMONDI, M. A. et al. Períodos de interferência das plantas daninhas na cultura do algodão em semeadura adensada na safrinha. Planta Daninha, Viçosa, v. 32, n. 3, p. 521-532, 2014.

SANTOS, J. B. et al. Interferência de plantas daninhas na cultura do quiabo. Planta Daninha, Viçosa, v. 28, n. 2, p. 255-262, 2010.

SCHOLTEN, R.; PARREIRA, M. C.; ALVES, P. L. C. A. Período anterior à interferência das plantas daninhas para a cultivar de feijoeiro 'Rubi' em função do espaçamento e da densidade de semeadura. Acta Scientiarum Agronomy, Maringá, v. 33, n. 2, p. 313-320, 2011.

STAGNARI, F.; PISANTE, M. The critical period for weed competition in French bean (Phaseolus vulgaris L.) in Mediterranean areas. Crop Protection, Guildford, v. 30, n. 1, p. 179-184, 2011.

TRANI, P. E. et al. Recomendações de adubação e calagem para berinjela, jiló, pimenta-hortícola e pimentão. In: RAIJ, B. V. et al. (Eds.). Recomendações de adubação e calagem para o Estado de São Paulo. 2. ed. Campinas: IAC, 1996, p. 173 .

WAMSER, A. F. et al. Influência do sistema de condução do tomateiro sobre a incidência de doenças e insetos-praga. Horticultura Brasileira, Brasília, v. 26, n. 2, p. 180-185, 2008.

WAMSER, A. F. et al. Produção do tomateiro em função dos sistemas de condução de plantas. Horticultura Brasileira, Brasília, v. 25, n. 2, p. 238-243, 2007. 